\title{
DEVELOPMENT PROGRAM EVALUATION OF THE INDONESIA PROGRAM FOR GOLD MEDAL FOR SPORTS OF TENNIS
}

\author{
Yayan Rubaeni* \\ Ministry of Youth and Sports Republic of Indonesia \\ yayanrubaeni@yahoo.co.id
}

\begin{abstract}
This study aimed to evaluate the sport of tennis for The Indonesia Program for Gold Medal) or Program Indonesia Emas PRIMA), which is an evaluation study using model context, input, process, product and outcomes (CIPPO). Research shows that: 1) context evaluation is good - it has a purpose, the legal basis and the analysis of an adequate community; 2) Input evaluation is enough has a mechanism of selection of athletes, coaches and managers, but need more socializations. The program needs some improvements such as; support facilities and infrastructure, national tennis training centre, adequate financial support, the necessity in involving the private and government enterprise; 3) Proccess evaluation is enough - planning and supervision of training has been well developed, but the implementation was not optimum, needs sport science embedded at the Team, and need more participation in international tournament; 4) Product evaluation is very bad - achievement of both as a Team and Individual athlete at the international multi event was not satisfied; 5) Outcomes evaluation is very good - this program provide more participation and opportunity for junior athletes. Therefore, I would like to recommend that this program should be extended with some improvement as research suggested.
\end{abstract}

Keyword: Program Evaluation, CIPPO Model, The Indonesia Program for Gold Medal on Sport of Tennis.

Achievement of sport in the international multi - event is the culmination of the national sports system, the achievement of sports can not be obtained suddenly, but through a long process of planned, systematic, tiered and sustainable, with the support of various related elements, especially the support of sports science and technology.

Achievement sports are an effort to improve the ability and potential of sportsmen in order to improve the ability and potential of sportsmen in improving the dignity of the nation, which can be done by everyone who has the talent, ability and potential to reach achievement." (Law Number 3 Year 2005).

The main objective of the achievement of sport in the international event is to improve the dignity of the nation through sporting events, therefore the improvement of sports achievement should continue to be encouraged as part of efforts to improve the dignity of the nation in the international world and to enhance the sense of Indonesian nationalism. (Law No. 16 of 2007).

On SEA Games IX to XIX Indonesia's ranking is always on the top of the rankings of first and second, while the second rank is obtained on the SEA Games XIII and XVII, the rest of Indonesia is ranked first or the overall champion. Since the XX-XXVIII SEA Games edition, Indonesia's ranking continues to decline, only 
in SEA Games XXVI 2011 edition, As the host Indonesia succeeded to become the overall champion, the rest of Indonesia ranked highest in third position, even in the last two editions of SEA Games XXVII 2013 ranks fourth and SEA Games XXVIII 2015 in fifth rank (Kemenpora, 2015).

The above conditions are very unfortunate, given the great potential of the Indonesian nation to be able to compete in various international multi-event, the number of residents and the exercise antuasiasme are some potential that can be optimized as a foundation to achieve sports achievement.

To optimize the potential, strategic policy of the Government is required through a planned, systematic and sustainable program with the support of sports science and technology, one of the implementation of that, in 2007 the Government through the Ministry of Youth and Sports to create a "Indonesian Program for Gold Medal"., which is a program Sustainable, tiered and systematic national training with sports science and technology support, prepared for international sports multievent.

Furthermore, a more strategic reinforcement of the Government by strengthening the legal and political basis of the program through the stipulation of Presidential Regulation No. 22/2010 on Indonesian Program for Gold Medal (PRIMA). This program is a Government program to create national flagship athletes who are able to perform at the international level.

Presidential Regulation is a guarantee of Government support for a systematic and sustained national training program, both political and budgetary support, previously only temporary or non-sustainable. Through the support of this program Indonesia in 2011 succeeded as the overall Champion of SEA Games XXVI in 2011 in Jakarta, but in the next two events Indonesia ranked in the SEA Games event decreased dramatically after only ranked 4th in SEA Games XXVII 2013 in Myanmar and rank 5 at SEA Games XXVIII of 2015 in Singapore.

Considering that PRIMA is a strategic and major program in improving international sporting achievement, it is necessary to evaluate the above condition in order for the next international multi event especially SEA Games XIX 2017 in Malaysia can get better achievement.

Evaluation is the process of collecting and selecting information for subsequent analysis of the data obtained then concluded to be submitted to the relevant parties as the basis for making decisions regarding the substance in the evaluation.(Widoyoko, 2012).

Program evaluation is an evaluation that interprets an activity that provides service on a continuous basis and often involves the offerings of new methods for both education and training, which serve as a measure of the extent to which a goal has been achieved within a certain time according to the length of time Program (Yusuf, 2008).

In relation to PRIMA, evaluation should be conducted to collect and conduct the selection of relevant data for further scientific analysis so that it can be obtained conclusions that can be used as the basis for making decisions related to the development of PRIMA. The evaluation needs to be done thoroughly to all the sports involved in PRIMA, but considering the limitations of the authors, the research focuses on tennis sport.

Tennis is one of the kind of sport of Indonesia to achieve medals in the international multi-event, especially the SEA Games. At the 2011 SEA Games 
event in Palembang, the tennis reach 4 gold medals, exceeding the set target of 2 gold, at the SEA Games in 2013, the tennis sport is not contested. Furthermore at the SEA Games 2015 in Singapore tennis can not reach gold medals after losing to compete from the Philippines and Thailand team.

Overall, the condition of tennis achievement is shows a decline, one of which is shown by at least tennis players who ranked high in the International Tennis Federation (ITF), for the only male number Christopher Rungkat who is the number one Indonesian and ranked ITF 400s.

Based on the author's observation that the men's national tennis team since 2014 has not changed, always filled by Chrystopher Rungkat, David Agung Susanto, Adhitya Hary Sasongko and Sunu Wahyu Trijati. This is allegedly due to limited tennis players who play at the International level.

This is allegedly due to less optimal training program of tennis sports at PRIMA from preparation to implementation, therefore the authors are interested to conduct research on the evaluation of tennis coaching program at PRIMA.

\section{METHOD}

The objective of this program evaluation study is to know the effectiveness of Tennis Development Program in the Indonesian Program for Gold Medal (PRIMA) and specifically the evaluation aimed to find out the Program of Tennis Sport Development in Indonesian Program for Gold Medal (PRIMA) from context, input, process, Product and outcomes.

The study was conducted in Assistant Deputy for sports achievement Ministry of Youth and Sports, organization PRIMA, Tennis National Training PB PELTI, while the research was conducted from November 2016 in January 2017. Approach used in evaluative research with qualitative and quantitative approach. The data obtained confirmed to some parties to ensure the validity of the data (nail, 2007). The data were collated and reduced to a general pattern, classified and described to give a complete picture of the implementation of the Tennis Program on the Indonesian Program for Gold Medal (PRIMA).

The design of this evaluation study is presented in order to focus the research stages undertaken by the researcher can clear the exposure. The research design describes the flow of evaluation implementation on each evaluation component and describes the evaluation process of each component.

After starting with setting evaluation criteria based on legal basis and theoretical study. Further data is taken on each evaluation component. The data obtained were then analyzed and compared with the evaluation criteria. Data that do not fit the criteria are deepened by conducting interviews to determine the underlying causes and reasons as well as the constraints in achieving the criteria. Further assessment and determination of each component to be evaluated. The results of the analysis and decision making are then used as the basis for improving each component of the program and improving and making decisions on the implementation of the program.

Research subjects are the parties involved in the implementation of the program. The selected research subjects were stakeholders, ie athletes, tennis coaches, PB PELTI managers, Satlak Prima, the parties from the Ministry of Youth and Sports and other tennis communities, In addition to the informants from 
stakeholders, the subject of this study are also documents related to Tennis Sports Program in Indonesian Program for Gold Medal (PRIMA).

The study used several instruments adapted to the required data sources ie observation, interview guide, document study guide. The research instrument is a tool used to measure observed natural or social phenomena. Another opinion reveals the research instrument is written guidance on interviews or observations or a list of questions prepared to obtain information from respondents.

\section{RESULT AND DISCUSSION}

The research focuses on the evaluation of the tennis program on the Indonesian Program for Gold Medal (PRIMA), the research using the CIPPO evaluation model. The Component Context evaluation is focused on 1) the objectives, 2) the legal basis, 3) the needs analysis. Component Input evaluation focused on 1) athletes, 2) coach, 3) managers, 4) capacity of facilities and infrastructure, 5) capacity of funds. Process components, evaluation focuses on 1) planning of exercises, 2) training program implementation, 3) supervision. Product evaluation component is focused on 1) achievement in international multi event 2). Individual achievement. Component outcomes, evaluation focused on, impact on tennis program. Here are the results and discussion for each component evaluated:

\section{Context Evaluation Component}

Context evaluation is a detailed description of the views and needs of stakeholders or the community towards the existence of the tennis program on PRIMA which includes sub-focus of context components 1) objectives, 2) legal basis and needs analysis. The result of the research using questionnaire instrument to 30 respondents stated 9 people $(30,1 \%)$ very good, 13 people $(44,5 \%)$ good, 5 person $(15,5 \%)$ enough and 2 people $(9,3 \%)$ bad and $0 \%$ very bad.

The results of interviews and document studies show that the program, tennis sport at PRIMA has a comprehensive objective and includes short, medium and long term objectives as stated in Presidential Regulation No. 15 of 2016 on Amendment of Presidential Regulation No. 22 of 2010 on Indonesian Program for Gold Medal and Described in detail in the document of the strategic plan of winning the Indonesian Program for Gold Medal (PRIMA) in 2016 - 2017. Furthermore, based on interviews obtained that the community, especially the tennis players need PRIMA as part of the process of coaching and improving the performance of tennis.

According to the description, the results of the research on the context component found that in 2016 revision of Presidential Decree Number 22 of 2010 on Indonesian Program for Gold Medal (PRIMA) became Presidential Regulation No. 15 of 2016 on Indonesian Program for Gold Medal (PRIMA), several substantial changes that is :

a. PRIMA is directed to prepare international multi-event such SEA Games, Asian Games, the Olympics were previously included preparing for the championship. It is quite positive because PRIMA become more focused on winning strategy Achievements on multi events.

b. The selection athletes is not only derived from the proposed of organization of the sport, but after the change is added that the selection athletes can also derive from the public proposal. According to the researchers this is very positive, as 
part of the Government service to the public that all citizens are entitled to follow the selection as a candidate for national team at PRIMA and minimize collusion in recruitment.

c. Changes to the organizational structure of the Executive Board, previously held by the Chairman of KONI, became the government's representative. This change according to the researchers is the impact of the unclear process of sports development achievement in Indonesia, the division of tasks and functions between the parties directly related to the process of sports achievement is not clear.

The division of duties and functions between the Government, KONI, KOI, Organization of Sports and with Satlak PRIMA not yet clear, so that impact on operational satlak PRIMA. From the Government's perception that PRIMA is a strategic program of the Government so that the Government in this case Kemenpora has the right to be directly involved as the executor, while on the other hand the KONI which is the strategic partner of the Government in formulating the policy of increasing the sport achievement also has the role as the technical implementer of the improvement of sport achievement. According to the researchers, the Government and KONI should coordinate and synergize in an effort to jointly facilitate the Organization of the Sports to achieve PRIMA in improving the achievement of athletes according to each sports.

\section{Input Evaluation Components}

Implementation of the evaluation on the Input component is the process of recording and identification of the potential or resources owned by the Indonesian Program for Gold Medal (PRIMA) in particular the tennis sport, while the evaluation process focuses on sub-components a) athletes, b) coaches, c) managers, d) Support of facilities and infrastructure, and e) financial support.

The results of the research through questionnaires to 30 respondents obtained 5 people $(16,7 \%)$ very good, 5 people $(16,7 \%)$ good, 13 people $(43,3 \%)$ enough, 4 people bad (13,3\%), And 2 people $(6,8 \%)$ is very bad.

While based on the results of interviews and document studies obtained research findings as follows :

a. The tennis program at PRIMA has standards, mechanisms and criteria for athlete selection and how the promotion and degration mechanisms of athletes over a period of time, as stated in the document of the Strategic Plan of Gold Indonesia Program Winning (PRIMA) 2016 - 2019. At the implementation level it is found that The process has not been transparent, as evidenced by the lack of socialization related to the selection process of the Indonesian tennis community, so there are allegations that indicate the selection based on the appointment of organization of sport.

b. Facilities and infrastructure of tennis sport program at PRIMA is accordance with International Tennis Federation (ITF) facilities and infrastructure standard, however, based on observation it is found that the infrastructure used is not owned by the organization or PRIMA so that the training process is often sedentary because of difficulties Looking for usable field.

The condition should be the thinking of all parties to start preparing the international-standard sports center as a place of coaching and tennis 
training, so that the program has been arranged can run in a systematic and sustainable.

c. The findings of the study indicate that the funding source for the operational of the tennis sport program at PRIMA comes from the sharing of parties, mainly from the PRIMA satlak and part of the PB PELTI, but as expressed by the tennis team manager who is also the deputy secretary general of PB PELTI that the ideal funding requirement for optimization The program is

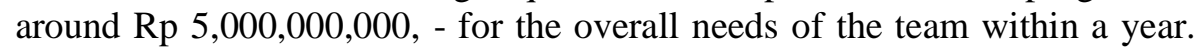
While the facilitation fund from PRIMA average per year is only about Rp.1.000.000.000, - or about 20-30\% per year.

These conditions have an impact on the implementation of the entire program that has been planned especially the participation program in international tournaments.

The ideal condition of the program, in a year should be to follow the 23-25 international tennis tournaments of either $\$ 10,000$ or $\$ 25,000$, this is absolutely necessary to earn points in order to raise the single and double ratings of the International Tennis Federation (ITF). The ranking is a reference for participation in multi international events such as the SEA Games, the Asian Games and the Olympics. For example in some Asian Games events, Indonesian tennis teams can not participate due to low ITF ratings of players.

One solution that can be reached, amid the limitations of APBN allocation for PRIMA is by holding private parties to sponsor tennis team, this can be done by facilitation from PRIMA or Kemenpora by finding private party or BUMN to sponsor. Aside from being a team, PB PELTI and Satlak PRIMA can facilitate the tennis athletes incorporated in PRIMA to obtain individual sponsorship so that the need to participate in an international tennis tournament can be fulfilled.

\section{Evaluation Component Process}

Implementation of evaluation on process component is an evaluation process at planning stage of training, execution of practice and supervision of Indonesian Program for Gold Medal (PRIMA) especially sport tennis, while evaluation process focus on sub component a) planning, b) implementation, c) supervision.

The results of the research through questionnaires to 30 respondents obtained 5 people $(16,7 \%)$ very good, 7 people $(23,3 \%)$ good, 9 people $(30,0 \%)$ enough, 7 people $(23,3 \%)$ bad, And 2 people $(6.7 \%)$ are very bad.The results of interviews and document studies show that the training process begins with planning the exercises and becomes the reference in the implementation of the exercise, while the monitoring mechanism is carried out by Satlak PRIMA and PB PELTI by conducting periodic evaluation and monitoring for each phase of the exercise.

The research findings indicate that sports science support is not optimal because the sports science team is not specific to the tennis branch but for some sports games, so the support is not optimal, this has an impact on the not optimal increase of skills, attitudes and cognition of tennis athletes significantly.

According to the researchers should the sports sciene team in attached to the tennis team in order to monitor and facilitate the team optimally and periodically. So that the performance of the player can be monitored and faster, so it can compete with the tennis players of the world. 


\section{Product Evaluation Component}

Implementation of evaluation on product component is evaluation process to know result of program implementation of tennis sport at Indonesian Program for Gold Medal (PRIMA) especially sport tennis putra, while evaluation process focus on sub component a) achievement at multi international event, b) individual achievement.

The result of the research through questionnaire to 30 respondents obtained 1 person $(2.2 \%)$ very good, 2 people $(5,6 \%)$ good, 7 people $(22,2 \%)$ enough, 8 people $(27,8 \%)$ bad, and 13 people $(42,2 \%)$ is very bad.

Based on the results of interviews and document studies obtained that the achievement of tennis at the SEA Games 2015 is very concerned about not getting a gold medal, after the previous SEA Games edition in 2011 Indonesia as the overall champion (SEA Games 2013, tennis is not contested). Individual achievements of tennis athletes incorporated in the PRIMA squad with reference ratings of the ITF have not been satisfactory, recorded only Chrystopher Rungkat who ranked 400s and David Agung 800s while other athletes in the 1000's.

The above conditions as a result of the lack of international tournaments so as not to get the points that are the main requirement to raise the rating of the ITF, this also impacts on the participation in international multi-events such as the SEA Games and the Asian Games because ITF rank becomes a reference to whether or not to participate in The event.

\section{Evaluation Components Outcomes}

Implementation of the evaluation on the Outcomes component is an evaluation process to determine the impact of the implementation of tennis sport program in Indonesian Program for Gold Medal (PRIMA), especially the sports tennis putra on the community, while the evaluation process focuses on the participation level of junior athletes. The results of the research through questionnaires to 30 respondents obtained 13 people $(41.7 \%)$ very good, 11 people (36.7\%) good, 4 people $(13.3 \%)$ enough, 3 people $(8.3 \%)$ bad, And 0 people $(0 \%)$ is very bad.

The results of interviews and document studies show that the tennis program at PRIMA has an impact on the overall process of tennis coaching, as well as the increased participation of junior athletes in national tournaments. The condition occurs because after passing the age group of 16 years the majority of athletes intending to follow the national selection to be elected into the PRIMA squad to continue to strengthen the national tennis team in various international events. Therefore, the tennis program at PRIMA needs to be continued and optimized as part of the overall tennis development process.

\section{REFERENCES}

Daniel L, Stufflebeam \& Chris L.S Coryn, Evaluation Theory, Models \& Application, San Fransisco; Jossey-Bass, 2014

Eko Putro Widoyoko, Evaluasi Program Pembelajaran. Yogyakarta: Pustaka Pelajar, 2012 
Evaluasi Sea Games 2015. Kemenpora, 2015

Farida Yusuf Tayibnapis, Evaluasi Program dan Onstrumen Evaluasi, Jakarta: PT Rineka Cipta,2008

ITF Rules and Regulation. London : ITF, 2016

James Tangkudung, Wahyuningtyas Puspitorini, Kepelatihan Olahraga;Pembinaan Prestasi Olahraga. Jakarta, Cerdas Jaya: 2012

Peraturan Pemerintah Nomor 16 Tahun 2007 Tentang Penyelenggaraan Pekan dan Kejuaraan Olahraga. Kemenpora, 2012

Penyajian Data dan Informasi Kepemudaan dan Keolahragaan. Kemenpora, 2014

Rencana Strategis Kemenpora 2016-2019. Kemenpora.2016

Saryono dan Mekar, D.A, Metodelogi Penelitian Kualitatif dalam Bidang Kesehatan. Yogyakarta: Muha Medika, 201)

Suharsimi Arikunto, Cepi Safrudin Abdul Jabbar, Evaluasi Program Pendidikan Jakarta, Bumi Aksara, 2009

Suharsimi Arikunto, Cepi Safruddin Abdul Jabbar, Evaluasi Program Pendidikan. Jakarta, Bumi Aksara, 2009

Suharsimi Arikunto, Prosedur Penelitian Suatu Pendekatan Praktik. Jakarta: Asdi Mahasatya, 2010.

Sugiyono, Metode Penelitian Kombinasi (Mixed Methods). Bandung: PT. Alfabeta, 2011.

Tennis Canada. High Performance Handbook.Toronto, Sorenham, 2012

Tudor O. Bompa dan G.Gregory Haff. Periodization:Theory and Methodology of Training. United States : Human Kinetics.2009.

Wirawan, Evaluasi : Teori, Model, Standar, Aplikasi dan profesi. Jakarta: PT.Rajagrafindo Persada, 2011

Undang-Undang Nomor 3 Tahun 2005 tentang Sistem Keolahragaan Nasional. Kemenpora, 2011. 